\title{
Perilaku Alami dan Tidak Alami Burung Kakatua Jambul Kuning (Cacatua sp.) di Animal Sanctuary Trust Indonesia, Jawa Barat
}

\author{
Natural and Stereotype Behavior of Yellow-Crested Cockatoo \\ (Cacatua sp.) in Animal Sanctuary Trust Indonesia, West Java
}

\author{
EKA ARISMAYANTI ${ }^{*}$, NISFIA RAKHMATUN NISA ${ }^{1}$, ALFATH FANIDYA ${ }^{1}$, WILDAN ARSYAD F ${ }^{1}$, NADYA \\ AULIA PUTRI ${ }^{2}$, RIKA RAFFIUDIN ${ }^{1}$, KANTHI ARUM WIDAYATI ${ }^{1}$ \\ ${ }^{1}$ Departemen Biologi, Fakultas Matematika dan Ilmu Pengetahuan Alam, Institut Pertanian Bogor, Kampus IPB \\ Dramaga, Bogor 16680 \\ ${ }^{2}$ Animal Sanctuary Trust Indonesia, Jl. Cikopo Selatan No. 14 Sukamanah, Kec. Mega Mendung, Bogor 16770
}

Diterima 14 Mei 2021/Disetujui 25 Mei 2021

\begin{abstract}
Cockatoo (Cacatua sp.) is one of birds that is widely distributed in Indonesia and often kept as pet, thus threatening the Cacatua population in the wild. Environmental condition may affect the behavior of Cockatoo. Some unnatural behavior may arise due to living in the captive. Different cage conditions may result in different behavior performance in Cockatoo. Research on daily behavior at animal rescue sites at ASTI Bogor has never been conducted. This study aimed to analyze natural and stereotype behavior of Cacatua sp. at animal rescue center due to foreclosure, and analyze the relationship between cage condition and environmental factors. This study used focal instantaneous sampling, using eight individuals Cacatua sp. Cacatua sp. in ASTI performed natural behavior more than unnatural behavior, therefore ASTI can be a good place for animal rescue. The dominant natural behaviors were Resting (Re), Preening (Pr), Feeding (Fe), Locomotion (Lo), and Fighting (Fg), while unnatural behaviors were play, bite, abnormal vocalization, feather picking and aggressive. There are no difference in behavior between male and female, and also behavior in the morning and afternoon $(p>0.05)$, but cage condition had a significant effect to daily behavior of Cacatua sp. $(<0.05)$.
\end{abstract}

Key words: Natural behavior, Stereotype behavior, Cacatua sp., captivity

\section{PENDAHULUAN}

Burung kakatua (Cacatuidae) merupakan burung yang memiliki ukuran tubuh sedang hingga besar, biasanya berwarna putih dan beberapa jenisnya memiliki jambul yang ditegakkan pada saat menunjukkan perilaku terkejut. Burung kakatua yang paling populer dipelihara adalah jenis burung kakatuajambul kuning (Cacatua sp.) seperti Cacatua galerita dan C. sulphurea (Harcourt-Brown 2009). Kakatua jambul kuning tersebar mulai dari Indonesia di pulau Sulawesi dan Kepulauan Sunda Kecil, hingga Pulau Penida dan Salembu Besar di Laut Jawa (White dan Bruce 1986; Coates dan Bishop 1997). Kakatua jambul kuning telah mengalami penurunan populasi yang sangat cepat karena diburu untuk perdagangan sehingga jenis ini tidak hanya

*Penulis korespondensi:

E-mail: arismayanti.eka@gmail.com ditemui di habitat alaminya saja (Bashari dan Arndt 2016). Kakatua jambul kuning banyak dipelihara oleh manusia dan menyebabkan jenis burung ini dapat memperlihatkan perilaku tidak alami karena adanya pemeliharaan.

Perilaku alami kakatua jambul kuning (Cacatua sp.) yaitu terdiri atas perilaku makan, bersarang dan beristirahat (Styche 2000; Rumanta et al. 2019). Kakatua memilih lokasi bersarang yang berbeda dengan lokasi pohon pakan (Rumanta et al. 2019). Selain itu yang termasuk perilaku alami adalah perilaku makan, terbang, berpindah tempat, bertengger, mematuk benda, membersihkan badan, membuang kotoran, dan interaksi antar individu pada Cacatua moluccensis (Anggraeni et al. 2016), serta perilaku mandi pada Cacatua sulphurea sulphurea (Gita et al. 2012). Perilaku lain yang dapat di temukan pada individu kakatua jambul kuning yaitu perilaku tidak alami. Perilaku tidak alami yang sangat mudah diketahui adalah dilakukannya 
feather picking, perilaku ini sangat banyak ditemui pada individu yang berada di captive. Feather picking merupakan perilaku abnormal berdasarkan dengan perilaku preening yang dapat dilakukan oleh burung (Seibert 2006). Perilaku tidak alami dapat mengindikasikan bahwa lingkungan di sekitar satwa tidak optimal dan dapat membatasi aktivitas satwa (Rojahn et al. 1997).

Perilaku alami maupun tidak alami sangat dipengaruhi oleh faktor lingkungan di habitatnya. Suhu merupakan faktor lingkungan yang sangat mempengaruhi energi yang dihasilkan oleh burung. Faktor lingkungan lain yang dapat berpengaruh terhadap perilaku satwa adalah faktor kandang. Bentuk kandang, kepadatan individu dalam kandang, penghalang pada kandang, serta letak pemberian makan pada kandang dapat berpengaruh terhadap perilaku Burung kakatua (Quart dan Adam 1981). Hal ini mengindikasikan bahwa kakatua yang tinggal di tempat berbeda akan menunjukkan perilaku yang berbeda pula.

Perilaku mengenai kelompok kakatua yang berasal dari tempat transit penyelamatan satwa belum pernah dilakukan. Pusat penyelamatan satwa yang menjadi tempat transit bagi hewanhewan sitaan sangat diperlukan sebelum hewan dapat dilepas liarkan kembali ke habitat alaminya. Salah satu tempat penyelamatan burung kakatua jambul kuning (Cacatua sp.) yang telah disita dari pemeliharaan masyarakat berada di Animal Sanctuary Trust Indonesia (ASTI). Penelitian ini dilakukan dengan mencatat perilaku harian dari beberapa individu kakatua jambul kuning di ASTI dan menganalisa korelasi antara perilaku tersebut dengan kondisi kandang, jenis kelamin dan pengaruh lingkungan. Penelitian ini diharapkan dapat menjadi data dasar untuk meningkatkan konservasi eksitu Burung Kakatua Jambul Kuning.

\section{BAHAN DAN METODE}

Waktu dan Lokasi Penelitian. Pengamatan dilakukan selama dua hari pada tanggal 15 dan 16 Februari 2020, selama 960 menit pengamatan. Pengambilan data di lakukan di Animal Sanctuary Trust Indonesia (ASTI) yang berlokasi di Gadog, Mega Mendung, Jawa Barat. Analisis data dilakukan di Departemen Biologi, Institut Petanian Bogor, Jawa Barat. Analisis data dilakukan pada tanggal 24 Februari hingga 3 April 2020.

Subjek Penelitian dan Deskripsi Kandang. Delapan ekor burung Kakatua Jambul Kuning (Cacatua sp.) diamati setiap perilaku hariannya. Terdapat dua jenis Kakatua Jambul Kuning yang diamati yaitu enam ekor Kakatua Jambul Kuning
Besar (Cacatua galerita) dan dua ekor Kakatua Jambul Kuning Kecil (Cacatua sulphurea). Satwa ini merupakan hasil sitaan dari kolektor satwa liar dan perdagangan ilegal. Seluruh individu diidentifikasi dengan melihat tanda khusus pada tubuh seperti bentuk dan ukuran tubuh, warna bulu, bekas luka, dan lain-lain. Setiap individu diberi nama berbeda berdasarkan kode nama ASTI (Tabel 1). Burung Kakatua ditempatkan pada kandang kecil (Gambar 1) dan kandang besar (Gambar 2) yang terletak diluar bangunan utama. Penelitian dilakukan pada enam kandang yang berada di ASTI, kandang tersebut diberi nomor 2, 4, 6, 7, 8, dan 9. Kandang no. 2 memiliki ukuran $2 \times 4 \mathrm{~m}$, yang dihuni oleh tiga ekor burung kakatua jambul kuning. Kandang no. 4 berukuran 2 $\times 4.5 \mathrm{~m}$, kandang tersebut berisi tiga ekor burung. Kemudian kandang no. 6,7 , dan 8 berukuran $2.2 \times$ $1.15 \mathrm{~m}$, masing-masing kandang hanya berisi satu individu. Terakhir yaitu kandang 9 yang dihuni oleh satu individu berukuran $1.6 \times 0.9 \mathrm{~m}$. Individu yang

\begin{tabular}{clll}
\multicolumn{4}{l}{ Tabel 1. Data individu kakatua jambul kuning } \\
\hline Kandang & $\begin{array}{l}\text { Nama } \\
\text { individu }\end{array}$ & Asal sitaan & $\begin{array}{l}\text { Tanggal } \\
\text { masuk ASTI }\end{array}$ \\
\hline 2 & Cassey & KSDA Jakarta & 15 Mei 2015 \\
2 & Snowball & KSDA Serang & 16 Januari 2013 \\
4 & Ray & PPSTA & 07 Agustus 2004 \\
4 & Ratna & Lampung & 04 Oktober 2003 \\
6 & Blizard & KSDA Serang & 13 Mei 2015 \\
7 & Rani & BKSDA Bogor & 22 April 2017 \\
8 & Coffey & PPSTA & 10 Juni 2004 \\
9 & Stevie & KSDA DKI & 15 Mei 2015 \\
\hline
\end{tabular}

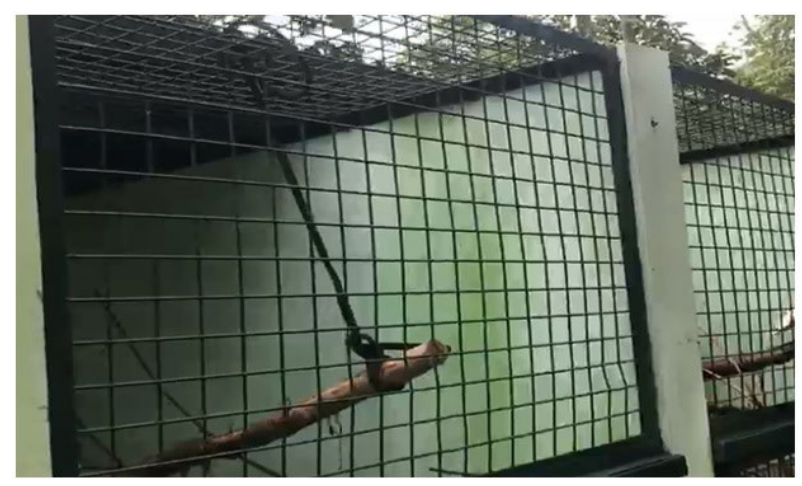

Gambar 1. Kandang ukuran kecil

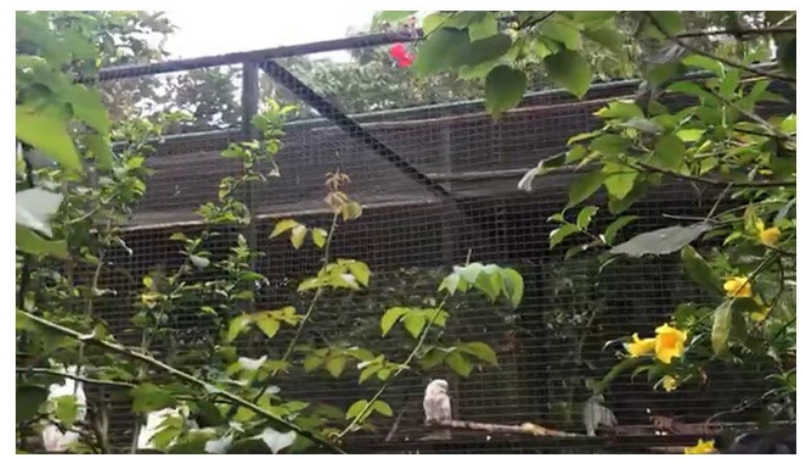

Gambar 2. Kandang ukuran besar 
diamati pada penelitian berada pada kandang 2 yaitu Snowball dan Casey, pada kandang 4 yaitu Ratna dan Ray, pada kandang 6, 7, 8, yaitu Blizzard, Rani, dan Stevie. Trakhir pada kandang 9 yaitu Coffey.

Prosedur Pengamatan. Pengambilan data perilaku dilakukan menggunakan focal instantaneous sampling (Martin dan Bateson 1993). Peneliti mengamati perilaku satu individu dalam waktu yang telah ditentukan dan mengikuti kemanapun focal target pergi. Pengamatan dilakukan selama 30 menit dengan interval pencatatan selama satu menit. Waktu pengamatan dibagi menjadi dua yaitu periode pengamatan yaitu, pagi hari dari pukul 09.00-12.30 WIB, dan siang hari dari pukul 12.30-16.00 WIB. Pengamat akan mengamati individu burung dengan jarak satu hingga dua meter dari kandang, dengan melakukan kamuflase memakai baju gelap yang sama selama masa pengamatan dan berada di sisi yang tidak terlihat oleh individu burung kakatua yang akan diamati. Masing-masing pengamat mengamati dua individu burung dengan jeda waktu istirahat selama 15 menit setelah 30 menit pengambilan data. Data perilaku harian yang diamati yaitu perilaku harian yang bersifat alami dan tidak alami (Tabel 2) (Noske 1980; Styche 2000; Meehan et al. 2003, 2004; Kinkaid 2015).

Pengukuran Variabel Lingkungan. Pengukuran suhu dan intensitas cahaya dilakukan setiap pagi 09.00 WIB dan siang hari 12.30 WIB selama periode pengamatan. Pengambilan data suhu menggunakan Thermohigrometer, dan intensitas cahaya menggunakan Lux meter. Suhu mikro (sekitar ASTI) dan angka yang tertera pada alat akan dicatat.
Analisis Data dan Statistik. Data aktivitas harian ditabulasi menggunakan pivot table. Proporsi perilaku harian dikelompokkan dan dihitung berdasarkan perbedaan waktu diurnal. Frekuensi aktivitas harian akan dihitung dengan formulasi:

$$
\text { Frekuensi aktivitas }(\%)=\frac{\text { aktivtas i }}{\begin{array}{c}
\text { total seluruh } \\
\text { perilaku }
\end{array}} \times 100
$$

Rata-rata perilaku dari setiap individu dikalkulasikan dan dianalisis untuk melihat pengaruh variable waktu dan jenis kelamin terhadap aktivitas burung kakatua. Sebaran normalitas presentase perilaku akan di analisa dengan Shapiro-wilk test. Analisis selanjutnnya dilakukan dengan ANOVA jika data tersebar normal dan Kruskal-Wallis test jika sebaran data tidak normal. Seluruh uji statistik diolah menggunakan perangkat lunak R (R Core Team 2015).

\section{HASIL}

Perilaku Harian Burung Kakatua (Cacatua sp.). Perilaku paling dominan dilakukan oleh Cacatua sp. pada penelitian ini yaitu Resting sebesar $42 \%$, Preening sebesar 19\%, Feeding sebesar 12\%, Lokomosi sebesar 11\%, dan Figthing sebesar 8\% (Gambar 3). Setiap individu dapat melakukan resting dengan interval lima sampai sepuluh menit. Perilaku resting pada masing-masing individu lebih tinggi pada siang hari dibandingkan pada pagi hari (Gambar $3)$.

\begin{tabular}{|c|c|c|}
\hline Perilaku & Keterangan & Kode \\
\hline \multicolumn{3}{|c|}{ Perilaku alami (Noske 1980; Styche 2000) } \\
\hline Fly & Aktivitas terbang & Fl \\
\hline Locomotion & Berjalan dan memanjat di dahan kayu, lantai kandang, dinding kandang & Lo \\
\hline Feed & Makan, memproses makanan, memanipulasi makanan, aktif mencari makanan, minum & $\mathrm{Fe}$ \\
\hline Preen/Auto groom & Melicinkan dan membersihkan bulu, membersihkan paruh, menggaruk kaki ke kepala & $\operatorname{Pr}$ \\
\hline Rest/rost & $\begin{array}{l}\text { Tidur dengan menyembunyikan kepala dibalik sayap, diam di lantai kandang atau dahan } \\
\text { dan tidak melakukan aktivitas apapun, duduk dengan mata terbuka }\end{array}$ & $\mathrm{Re}$ \\
\hline Bark stripping & Mengelupas kulit kayu & Bs \\
\hline Allopreening/Allogrooming & Memberiskan bulu individu lain, saling membersihkan antar dua individu & Ap \\
\hline Display & Vokalisasi pada pagi dan atau sore hari, melebarkan jambul, menganggukkan kepala & Ds \\
\hline Figthing & Konflik fisik dengan individu lain, baik kontak fisik maupun mengejar & $\mathrm{Fg}$ \\
\hline Nest attendance & Memeriksa sarang & $\mathrm{Na}$ \\
\hline \multicolumn{3}{|c|}{ Perilaku tidak alami } \\
\hline $\begin{array}{l}\text { Playing (Meehan et al. } \\
\text { 2004) }\end{array}$ & Bermain dengan enrichment & $\mathrm{Pl}$ \\
\hline $\begin{array}{l}\text { Bite/chew (Meehan et al. } \\
\text { 2004) }\end{array}$ & Menggigit kawat atau besi & $\mathrm{Bt}$ \\
\hline $\begin{array}{l}\text { Abnormal Vocalisation/ } \\
\text { Alarm call (Kinkaid 2015) }\end{array}$ & $\begin{array}{l}\text { Suara melengking dengan dada naik dan sayap dikepakkan secara terus menerus selama } \\
\text { satu hari penuh, vokalisasi untuk menarik perhatian manusia }\end{array}$ & Av \\
\hline $\begin{array}{l}\text { Feather picking (Meehan et } \\
\text { al. 2003) }\end{array}$ & Mencabut bulu, mencabut hingga lepas & $\mathrm{Fp}$ \\
\hline Agression (Kinkaid 2015) & Agresi terhadap observer atau keeper atau manusia & $\mathrm{Ag}$ \\
\hline
\end{tabular}

Tabel 2. Etogram perilaku alami dan tidak alami kakatua jambul kuning besar 
Delapan individu Cacatua sp. melakukan perilaku lokomosi yang berbeda-beda. Lokomosi yang dilakukan meliputi perilaku berjalan dari ranting bagian depan kemudian ke ranting bagian belakang, berjalan ke arah samping dan ke bagian atas kadang, dan mencoba untuk mengambil makanan yang diberikan oleh keeper. Selain itu, perilaku lokomosi sering dilakukan bersamaan dengan perilaku menggigit kawat besi dan display (vokalisasi dan mengangguk).

Perilaku feeding dilakukan oleh semua individu yang diamati dan seluruh individu memiliki jam makan yang sama, sehingga interval dan durasi makan dari setiap individu tidak jauh berbeda. Pemberian makan di ASTI dilakukan pada pagi yaitu pada pukul $09.00 \mathrm{WIB}$ dan siang pada pukul 12.00 WIB. Terdapat perilaku yang muncul pada dua individu saja yaitu perilaku fighting karena perilaku fighting dilakukan oleh dua individu yang berada pada kandang sama (kandang 2). Perilaku lain yang tidak dominan dilakukan yaitu perilaku Fly sebesar 0.9\%, Alloprrening sebesar 0.1\%, Bark stripping sebesar $2.2 \%$, Display sebesar $0.1 \%$, Nest attendance sebesar $0.1 \%$, Play sebesar $0.5 \%$, Bite sebesar 0.5\%, Abnormal Vocalisation sebesar $1.9 \%$, Feather picking sebesar $0.5 \%$, dan Agression sebesar 1.0\% (Gambar 3).

Periaku Harian Burung Kakatua (Cacatua sp.) Pada Waktu yang Berbeda (Pagi-Siang). Penelitian dilakukan pula untuk melihat perilaku kakatua jambul kuning berdasarkan perbedaan jam pengamatan. Secara umum perilaku burung kakatua pada pagi dan siang hari tidak berbeda secara signifikan (Kruskal-Wallis test, p-value $=0.406$ ), walaupun beberapa frekuensi perilaku berbeda antara pagi dan siang hari. Beberapa perilaku yang lebih dominan dilakukan oleh burung kakatua pada pagi hari, seperti lokomosi $13.6 \%$ dan preening $21.4 \%$. Perilaku yang dominan dilakukan pada siang hari yaitu resting $45.1 \%$, dan feeding 13.4\%. Selain itu, perilaku yang juga teramati dilakukan pada pagi hari diantaranya flying, bark stripping, feather picking, bite, abnormal vocalization, dan

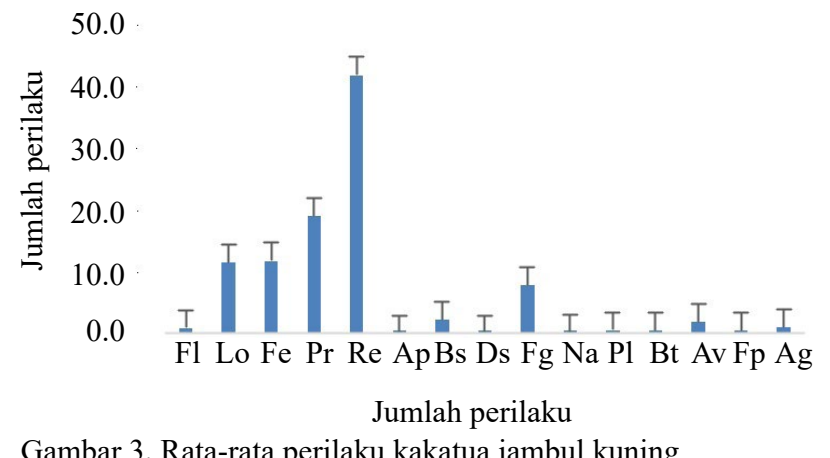

Gambar 3. Rata-rata perilaku kakatua jambul kuning aggressive, sedangkan perilaku pada siang hari yaitu flying, bark stripping, Allopreening, display, Nest attending, playing, feather picking, bite, abnormal vocalization, dan aggressive (Gambar 4).

Perilaku Harian Burung Kakatua Jambul Kuning (Cacatua sp.) Berdasarkan Perbedaan Sex (Jantan-Betina). Perilaku alami harian kakatua jambul kuning pada jantan dan betina tidak menunjukan perbedaan yang signifikan (Kruskalwallis test, $\mathrm{p}$-value $=0.8846$ ) walaupun terdapat perbedaan perilaku antara jantan dan betina. Salah satu perilaku yang cukup dominan di lakukan pada jantan yaitu resting pada pagi hari sebesar $47 \%$, perilaku lokomosi (12\%) dan fighting (10\%) juga cenderung dilakukan di pagi hari oleh kakatua jantan. Kakatua betina lebih menyukai perilaku feeding (14\%) dan preening (15\%) yang dilakukan pada pagi hari (Gambar 5). Kakatua jantan lebih aktif melakukan pergerakan dan perubahan gerakan seperti pada perilaku lokomosi, sedangkan pada burung kakatua betina lebih banyak melakukan perilaku yang tidak banyak melakukan perpindahan tempat, seperti pada perilaku preening. Perilaku seperti fighting, agresi, dan bark stripping pada kakatua jambul kuning hanya ditemui pada spesies jantan. Perilaku lain ditunjukan pula oleh kakatua betina yaitu perilaku abnormal vokalisasi yang dilakukan cenderung pada pagi hari.

Perilaku Alami dan Tidak Alami Burung Kakatua Jambul Kuning (Cacatua sp.). Berdasarkan hasil pengamatan, burung kakatua jambul kuning di ASTI lebih banyak melakukan aktivitas alami (95.9\%) dibandingkan perilaku tidak
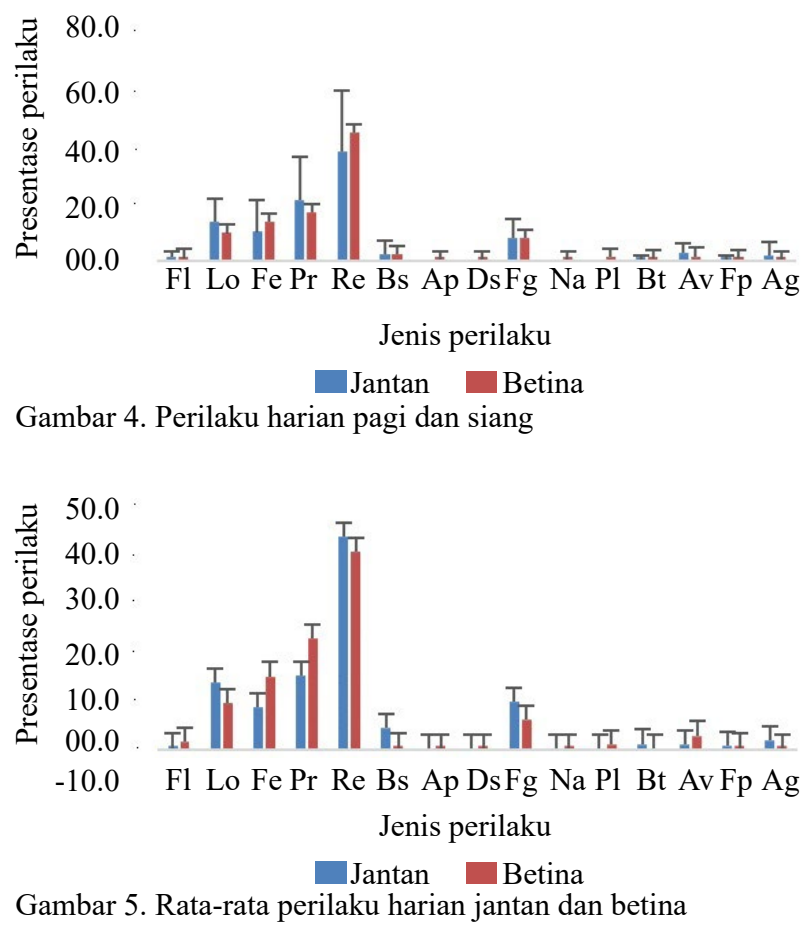
alami (Gambar 6). Persentase rata-rata perilaku alami dan perilaku tidak alami yang dilakukan burung kakatua jambul kuning jantan dengan burung kakatua jambul kuning betina menunjukkan bahwa aktivitas alami jauh lebih banyak dilakukan $(95.2 \%$ jantan dan $96.6 \%$ betina) (Gambar 7). Tidak terdapat perbedaan yang signifikan antara perilaku alami dan perilaku tidak alami yang dilakukan burung kakatua jambul kuning jantan dengan burung kakatua jambul kuning betina (Kruskal-Wallis test, $\mathrm{p}=0.8846$ ). Berdasarkan waktu pengamatan yang dilakukan pada pagi hari (09.00-12.30 WIB) dan siang hari (13.00-16.00 WIB) selama dua hari, aktivitas alami juga jauh lebih dominan dibandingkan perilaku tidak alami (94.7\% pagi $97.1 \%$ siang) (Gambar 7), dan tidak terdapat perbedaan yang signifikan terhadap perilaku alami dan perilaku tidak alami burung kakatua jambul kuning (Kruskal-Wallis test, $\mathrm{p}=0.4306$ ). Akan tetapi, hasil analisis statistik menunjukkan bahwa terdapat pengaruh ukuran kandang terhadap perilaku alami burung kakatua jambul kuning (Kruskal-Wallis, p-value $=0.01686)$.

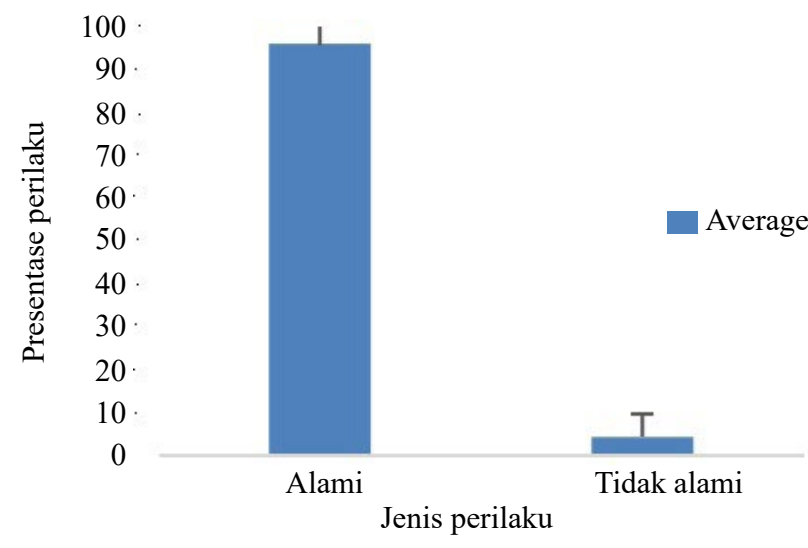

Gambar 6. Perilaku alami dan Tidak alami

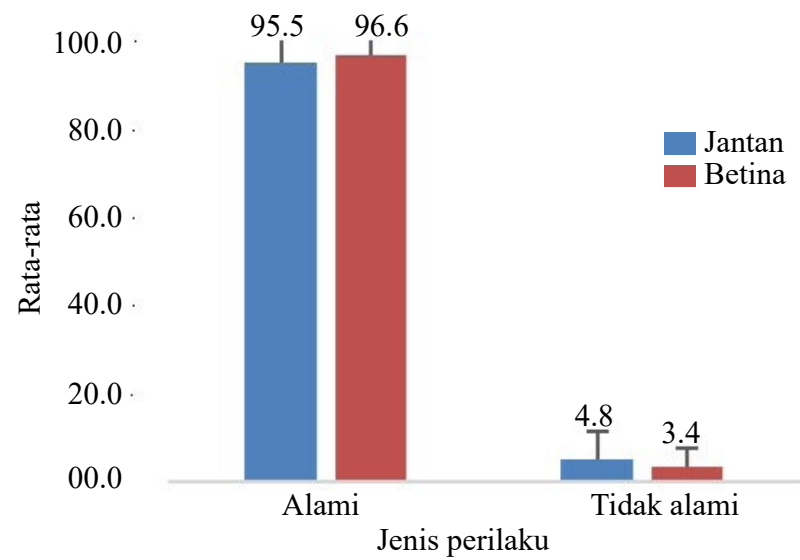

Gambar 7. Perilaku alami dan tidak alami berdasarkan jenis kelamin

\section{PEMBAHASAN}

Terdapat 15 perilaku harian Cacatua sp. dengan rata-rata jumlah perilaku tertinggi yaitu perilaku Resting (Re). Resting merupakan perilaku yang paling dominan dilakukan burung kakatua yang ditunjukkan dengan perilaku diam, bertengger, tidur, dan sesekali melihat keadaan sekitar. Gill (2007) mengungkapkan bahwa perilaku istirahat dilakukan sebagai upaya untuk mengurangi aktivitas agar suhu tubuh tidak meningkat. Hasil penelitian ini selaras dengan Anggraini et al. (2016) yang melaporkan bahwa perilaku burung kakatua dalam penangkaran didominasi oleh perilaku resting.

Perilaku dominan lainya yaitu Preening, Feeding, Lokomosi, dan Figthing, Preening (grooming) dalam penelitian ini biasanya dilakukan sekitar satu hingga lebih dari 30 menit tergantung pada masing-masing individu, menurut Van lersel dan Angela Bol (1958) preening dapat dilakukan pada intensitas waktu satu setengah detik dan preening dilakukan pada bagian bulu-bulu yang besar, bagian ekor, dan sayap. Individu kakatua di ASTI juga melakukan perilaku menggosokkan paruh ke kayu, selain menjaga kebersihan juga untuk menjaga agar kondisi paruh tetap baik (Lefebvre 1982; Rowley 1990). Satu individu pada kandang 6 melakukan perilaku feather picking, perilaku ini merupakan perilaku mencabuti bulu hingga lepas, perilaku ini dapat disebabkan oleh psikologi ataupun keadaan sosial dan lingkungan tempat tinggal yang tidak layak (Martens 1997) hal ini dapat terjadi karena kebiasaan yang dilakukan saat burung kakatua masih dalam tahap pemeliharaan ilegal oleh masyarakat, namun di ASTI perilaku tersebut telah semakin berkurang karena adanya perawatan dan tempat tinggal yang layak.

Perilaku dominan lainnya yaitu Fighting, perilaku fighting pada penelitian ini hanya ditemukan pada satu individu yang cukup agresif dan tinggal pada kandang 2 bersama dengan individu lain. Di alam perilaku ini biasanya dilakukan ketika kakatua melakukan konflik fisik dengan individu lain maupun mengejar untuk mempertahankan sarangnya (Kennedy 1990). Perilaku menyerang (Ag) juga diperlihatkan oleh salah satu individu kakatua terhadap keeper saat memberikan makan, individu melakukan agresi saat dirinya merasa terancam, hal ini dapat mengindikasi bahwa kakatua mempertahankan sifat alaminya, namun perilaku ini ditunjukkan oleh kakatua bersamaan dengan perilaku display (menegakan dan menundukkan 
kepala, menegakkan jambul dan membuka paruh). Bersuara (Ds) dilakukan untuk mempertahankan diri serta memikat betina dalam proses perkawinan (Rianti 2012) namun pada penelitian ini ditunjukkan dengan bersuara yang tidak normal (Av) hal ini dapat disebabkan karena dilakukan saat keeper sedang berada di sekitar kandang dan pada saat akan memberikan makan.

Penelitian ini juga mengamati perilaku burung kakatua pada waktu pengamatan yang berbeda, yaitu pagi dan siang hari (Gambar 8). Secara umum perilaku burung kakatua pada pagi dan siang hari tidak berbeda secara signifikan. Hasil ini berbeda dengan penelitian Styche yang menyatakan bahwa perilaku burung kakatua berbeda saat pagi dan siang hari (Styche 2000). Perbedaan hasil tersebut dapat dikarenakan kondisi cuaca yang didominasi hujan pada saat penelitian ini dilakukan (Tabel 3) dan waktu pengamatan yang kurang. Perilaku pagi hari burung kakatua jambul kuning di ASTI didominasi oleh perilaku lokomosi, terbang dan preening, sedangkan saat siang hari lebih banyak melakukan aktivitas istirahat dan makan. Bila dibandingkan dengan penelitian lainnya, burung kakatua di alam dominan melakukan lokomosi dan fly pada pagi hari (Symes dan Perrin 2003), dan perilaku istirahat lebih banyak dilakukan siang hari (Snyder 1987; Rowley 1990; Styche 2000; Wirminghaus et al. 2001). Sedangkan aktivitas makan dan preening dilakukan sepanjang pagi dan siang hari (Styche 2000). Hasil serupa juga dilaporkan oleh Abdillah (2017) terhadap perilaku harian burung kakatua jambul kuning besar di captive (Mega Orchid Farm), perilaku makan dan perilaku istirahat dominan pada siang hari, sedangkan aktivitas

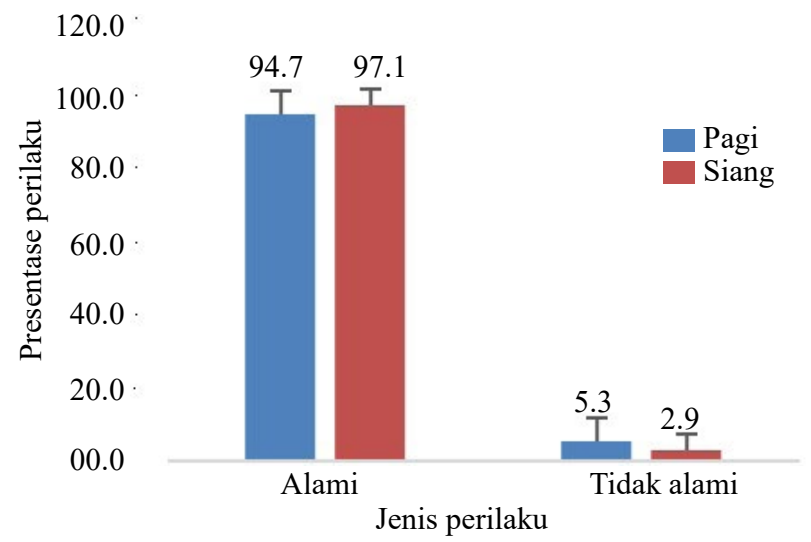

Gambar 8. Perilaku alami dan tidak alami berdasarkan waktu pengamatan

Tabel 3. Data parameter lingkungan

\begin{tabular}{lllc}
\hline Hari/tanggal & Waktu & Suhu & Intensitas cahaya \\
\hline Sabtu/15-02-2020 & Pagi & 32.7 & 36500 \\
& Siang & 30.0 & 5478 \\
Minggu/16-02-2020 & Pagi & 28.9 & 5910 \\
& Siang & 23.7 & 1046 \\
\hline
\end{tabular}

menelisik (preening) dilakukan sepanjang waktu mulai pagi hingga sore hari. Hasil tersebut menunjukkan bahwa waktu munculnya perilaku-perilaku kakatua jambul kuning jantan dan betina di ASTI pada pagi dan siang hari sesuai dengan perilaku burung kakatua yang muncul secara alami di alam maupun captive.

Kakatua jantan pada penelitian ini menghasilkan perilaku yang lebih aktif, perilaku aktif pada kakatua jantan salah satunya dalam bergerak (lokomosi). Hal ini sesuai dengan penelitian Rekarman et al. (2006) menyatakan bahwa pada umumnya satwa jantan lebih aktif bergerak dibandingkan dengan satwa betina. Selain itu saat berada di habitat alaminya, kakatua jantan lebih banyak melakukan perilaku sosial dibandingkan dengan kakatua betina, kakatua jantan lebih banyak bergerak untuk melawan predator, sedangkan kakatua betina akan lebih banyak bergerak untuk mencari makan (Meehan et al. 2003) dan lebih banyak melakukan perilaku preening (Snyder 1987; Rowley 1990).

Perilaku yang ditunjukkan oleh burung kakatua di lokasi Pusat Penyelamatan Satwa ASTI serupa dengan perilaku burung kakatua di captive dan alam liar (Murphy et al. 2011; Hailu et al. 2019). Perilaku alami masih dominan ditunjukkan oleh burung kakatua dibandingkan perilaku tidak alami (Gambar 6). Penanganan yang tepat dan enrichment yang diberikan dapat membantu burung untuk tetap melakukan aktivitas alaminya dan bertahan hidup dengan baik (Gitta et al. 2012; Bastari 2018), selain itu karena ASTI merupakan tempat penyelamatan satwa dan lokasi transit sementara, maka semakin lama keberadaan satwa tersebut di ASTI membawa pengaruh positif terhadap satwa tersebut, sehingga satwa dapat memiliki perilaku alami yang lebih dominan disbanding perilaku tidak alami (Tabel 1). Pada penelitian ini jenis kelamin, suhu, intensitas cahaya, dan waktu pengamatan tidak memberi pengaruh yang signifikan terhadap perilaku alami dan perilaku tidak alami burung kakatua jambul kuning (Tabel 4). Hal ini mungkin disebakan karena kurangnya periode waktu pengamatan yang telah dilakukan. Dalam beberapa penelitian mengenai perilaku pada burung kakatua, waktu pengamatan yang dilakukan adalah selama 5 hingga 12 hari (Gitta et al. 2012; Anggraini et al. 2016; Abdillah 2017). Namun, penelitian ini menemukan pengaruh signifikan ukuran kandang terhadap perilaku alami burung kakatua jambul kuning. Hal ini disebabkan karena kandang nomor 4 yang ditempati oleh tiga individu memiliki ukuran yang lebih besar dibandingkan dengan kandang 8 dan kandang 9 yang ditempati oleh masing-masing satu individu dan memiliki ukuran lebih kecil. Sehingga penggunaan ukuran kandang yang lebih besar mungkin dapat meningkatkan kualitas hidup Cacatua sp. di penangkaran dan pusat penyelamatan satwa. 
Tabel 4. Perhitungan statistik berdasakan variabel penelitian

\begin{tabular}{|c|c|}
\hline Indikator & Hasil (statistik, df, p-value) \\
\hline \multirow{4}{*}{$\begin{array}{l}\text { Perilaku } \\
\text { total }\end{array}$} & Shapiro test: $\mathrm{W}=0.87841, \mathrm{p}=0.002174$ (Sebaran data tidak normal) \\
\hline & Perilaku total vs Sex: chi-squared $=0.056295, \mathrm{df}=1, \mathrm{p}=0.8125$ \\
\hline & Perilaku total vs Waktu pengamatan: chi-squared $=0.076624, \mathrm{df}=1, \mathrm{p}=0.7819$ \\
\hline & Perilaku total vs kandang: chi-squared $=18.79, \mathrm{df}=5, \mathrm{p}=0.002103$ \\
\hline$\%$ Resting & Shapiro-wilk test: $\mathrm{W}=0.95856, \mathrm{p}=0.2671$ \\
\hline$\%$ Bark stripping & Shapiro-wilk test $: \mathrm{W}=0.49732, \mathrm{p}=3.468 \mathrm{e}^{-9}$ \\
\hline$\%$ Allopreening & Shapiro-wilk test $\mathrm{W}=0.17561, \mathrm{p}=4.636 \mathrm{e}^{-12}$ \\
\hline$\%$ Display & Shapiro-wilk test: $\mathrm{W}=0.85305, \mathrm{p}=0.0005887$ \\
\hline$\%$ Figthing & Shapiro-wilk test: $\mathrm{W}=0.17561, \mathrm{p}=4.636 \mathrm{e}^{-12}$ \\
\hline$\%$ Nest attendance & Shapiro-wilk test: $\mathrm{W}=0.17561, \mathrm{p}=4.636 \mathrm{e}^{-12}$ \\
\hline$\%$ Playing & Shapiro-wilk test: $\mathrm{W}=0.27361, \mathrm{p}=2.779 \mathrm{e}^{-11}$ \\
\hline$\%$ Bite & Shapiro-wilk test $\mathrm{W}=0.66795, \mathrm{p}=4.043 \mathrm{e}^{-7}$ \\
\hline$\%$ Abnormal vokalisasi & Shapiro-wilk test $\mathrm{W}=0.40112, \mathrm{p}=3.749 \mathrm{e}^{-10}$ \\
\hline$\%$ Feather picking & Shapiro-wilk test: $\mathrm{W}=0.35459, \mathrm{p}=1.393 \mathrm{e}^{-10}$ \\
\hline \multirow[t]{2}{*}{$\%$ Agresi } & $\begin{array}{l}\text { Shapiro-wilk test: } \mathrm{W}=0.35109, \mathrm{p}=1.295 \mathrm{e}^{-10} \\
\text { Shapiro test: } \mathrm{W}=0.76661, \mathrm{p}=1.308 \mathrm{e}-5 \text { (Sebaran data tidak normal) }\end{array}$ \\
\hline & Alami vs Sex: chi-squared $=0.021078, \mathrm{df}=1, \mathrm{p}=0.8846$ \\
\hline \multirow[t]{5}{*}{ \#Perilaku alami } & Alami vs Waktu pengamatan: chi-squared $=0.62117, \mathrm{df}=1, \mathrm{p}=0.4306$ \\
\hline & Alami vs Kandang: chi-squared $=13.81, \mathrm{df}=5, \mathrm{p}=0.01686$ \\
\hline & Alami vs Individu: chi-squared $=14.532, \mathrm{df}=8, \mathrm{p}=0.0689$ \\
\hline & Shapiro test: $\mathrm{W}=0.76661, \mathrm{p}=1.308 \mathrm{e}^{-5}:$ Sebaran data tidak normal \\
\hline & Tidak alami vs Sex: chi-squared $=0.021078, \mathrm{df}=1, \mathrm{p}=0.8846$ \\
\hline \multirow[t]{3}{*}{ \#Perilaku tidak alami } & Tidak alami vs Waktu pengamatan: chi-squared $=0.62117, \mathrm{df}=1, \mathrm{p}=0.4306$ \\
\hline & Tidak alami vs Kandang: chi-squared $=16.641, \mathrm{df}=5, \mathrm{p}=0.005235$ \\
\hline & Tidak alami vs Individu:chi-squared $=14.532, \mathrm{df}=8, \mathrm{p}=0.0689$ \\
\hline
\end{tabular}

\section{DAFTAR PUSTAKA}

Abdillah EB. 2107. Perilaku Harian Kakatua Putih Besar Jambul Kuning (Cacatua galerita). Di Mega Bird Orchid Farm Bogor [Skripsi]. Bogor, Indonesia: Institut Pertanian Bogor.

Anggraini DM, Rahayu SE, Susilowati. 2016. Perilaku harian burung salmoncrested cockatoo (Cacatua moluccensis) di penangkaran eco green park kota batu propinsi jawa timur. Ilmu Hayati 1:1-14.

Bashari H, Arndt T. 2016. Status of the critically endangered yellow-crested cockatoo cacatua sulphurea djampeana in the Tanahjampea islands, Flores Sea, Indonesia. Forktail $32: 62-65$.

Bastari R. 2018. Studi Pustaka Kesejahteraan Hewan Pada Sistem Perkandangan Burung Kakatua Jambul Kuning (Cacatua galerita) [Skripsi]. Bogor, Indonesia: Institut Pertanian Bogor.

Coates BJ, Bishop KD. 1997. A guide to the birds of Wallacea Alderley: Dove Publications.

Gill F. 2007. Ornithology 3rd Ed. New York: WH Freeman Company.

Gitta A, Masy'ud B, Suzzana E. 2012. Aktivitas Harian Dan Perilaku Makan Burung Kakatua-Kecil Jambul Kuning (Cacatua sulphurea sulphurea Gmelin 1788) Di Penangkaran. Media Konservasi 17:23-26.

Hailu T, Aynalem S, Yazezew, D. 2019. Activity Pattern, Flocking Behavior and Habitat Preference of Yellow Fronted Parrot (Poicephalus Flavifrons) In Zegie Forest, Southern Shore of Lake Tana, Ethiopia.

Harcourt-Brown NH.2009. Handbook of Avian Medicine (Second Edition). Edinburgh: Elsevier.

Kennedy KA, Draper DD. 1990. Common psittacine behavioral problems. Iowa State University Veterinarian 53:21-25.

Kinkaid MD. 2015. Species-Level Determinants of Stereotypic Behaviour, Reproductive Success, and Lifespan in Captive Parrots (Psittaciformes) [Thesis]. Canada: The University of Guelph.

Lefebvre L. 1982. The organization of grooming in budgerigars. Behavioural Processes 7:93-106.
Martin P, Bateson P. 1993. Measuring Behaviour: An Introductory Guide. 2nd ed. Cambridge: Cambridge University Pr.

Meehan CL, MillamJR, Mench JA. 2003. Foraging opportunity and increased physical complexity both prevent and reduce psychogenicmfeather picking by young Amazon parrots. Appl 80:71-85.

Meehan CL, Garner JP, Mench JA. 2004. Environmental enrichment and development of cage stereotypy in Orange-winged Amazon parrots (Amazona amazonica). Developmental Psychobiology Dev 44:209-218. DOI:10.1002/dev.20007

Martens PA. 1997. Pharmacological treatment of feather picking in pet birds. In: Mills DS, Heath SE.(Eds.). Proceedings of the First International Conference on Veterinary Behavioral Medicine, UFAW, UK. Potters Bar. p. 209-213.

Murphy SM, Braun JV, Millam JR. 2011. Bathing behavior of captive Orange-winged Amazon parrots (Amazona amazonica).Appl 132:200-210.

Noske S. 1980. Aspects of the behaviour and ecology of the White Cockatoo (Cacatua galerita) and Galah (C. roseicapilla) in croplands in north-east New South Wales [unpublished master Thesis]. New South Wales: University of New England Armidale.

Quart MD, Adam AW. 1982. Effects of cage design and bird density on layers: bird movement and feeding behavior. Poultry Science 61:1614-1620.

R Core Team. 2015. R: A language and environment for statistical computing. R Foundation for Statistical Computing, Vienna, Austria. Available at: https://www.R-project. org/ [Tanggal diakases: 1 April 2020]

Rekapermana M, Thohari M, Masy'ud B. 2006. Pendugaan jenis kelamin menggunakan ciri-ciri morfologi dan perilaku harian pada gelatik jawa (Padda oryzivora Linn 1758) di penangkaran. Media Konservasi 11:89-97.

Rianti D. 2010. Perilaku prakawin burung cenderawasih belah rotan (Cicinnurus magnificus) di Syoubri kawasan penyangga cagar alam pegunungan arfak [Skripsi]. Manokwari, Indonesia: Fakultas Matematika dan Ilmu Pengetahuan Alam Universitas Negeri Papua.

Rojahn J, Tasse MJ, Sturmey P. 1997. The stereotyped behavior scale for adolescent and adults with mental retardation. Am J Ment Retard 102:137-146. 
Rowley I. 1990. Behavioral ecology of the galah, Eolophus roseicapillus: In the wheatbelt of Western Australia. Chipping Norton, NSW: Surrey Beatty.

Rumanta M, Lelloltery H, Kunda RM, Kakisina P. 2019. Selection of plants species as feed sources and nesting places salmoncrested cockatoo (Cacatua moluccensis) Maluku Endemic in Manusela National Park (MNP). Adv Anim Vet Sci 7:474-479.

Seibert LM. 2006. Feather-Picking Disorder in Pet Birds. USA: Blackwell Publishing Professional.

Snyder NFR. 1987. The parrots of Luquillo: Natural history and conservation of the Puerto Rican parrot. Los Angeles: Western Foundation of Vertebrate: Zoology.

Styche A. 2000. Distribution and behavioural ecology of the sulphur-crested cockatoo (Cacatua galeria L.) in New Zealand [Thesis]. New Zealand: Victoria Univenity of Wellington.
Symes CT, Perrin MR. 2003. Daily flight activity and flocking behaviour patterns of the Greyheaded Parrot Poicephalus fuscicollis suahelicus Reichenow 1898 in Northern Province, South Africa. Tropical Zoology 16:47-62.

Van Iersel JJA, Angela Bol AC. 1958. Preening of two tern species. A study on displacement activities. Behaviour 13:1-88.

White CMN, Bruce MD. 1986. The birds of Wallacea (Sulawesi, the Moluccas and Lesser Sunda Islands Indonesia. An annotated checklist. London: British Ornithologists'Union (Checklist no. 7).

Wirminghaus JO, Downs CT, Perrin MR, Symes CT. 2001. Abundance and activity patterns of the cape parrot (Poicephalus robustus) in two afromontane forests in South Africa. African Zoology 36:71-77. 